\title{
Artificial intelligence and machine learning in orthodontics
}

\section{Ortodontide yapay zeka ve makine öğrenimi}

\author{
Süleyman Kutalmış Büyük ${ }^{1 *}$ (D), Sedanur Hatal ${ }^{1}$ \\ ${ }^{1}$ Department of Orthodontics, Faculty of Dentistry, Ordu University, Ordu, Turkey \\ * Corresponding author: Suleyman Kutalmış Buyuk E-mail: skbuyuk@gmail.com ORCID: 0000-0002-7885-9582 \\ Received: 1 April 2019 Accepted: 14 May 2019
}

\begin{abstract}
Objective: The clinical use of information technology in orthodontics has increased significantly in recent years. The aim of this systematic review is to perform a scientific analysis of artificial intelligence and machine learning in orthodontics.

Methods: An electronic search and manual search were performed on September 25, 2018 about using artificial intelligence and machine learning in orthodontics.

Results: A total of 107 studies were found. Nine studies were excluded because of duplication. After exclusion of all the irrelevant and non-English articles, 23 full-text articles remained to be included in this systematic review. 3 additional articles were included in this systematic review. Twelve automatic cephalometric landmark determination, 6 orthodontic diagnosis and treatment outcomes, 2 orthodontic tooth extraction decision, 3 facial attractiveness, 1 headgear selection, 1 touchless sterilisation system and 1 automatic skeletal age determination studies were included in this systematic review.

Conclusions: Artificial intelligence and machine learning are mainly focused on determination of automatic cephalometric points, facial attractiveness and tooth extraction decisions for orthodontic purposes. The use of artificial intelligence in orthodontics is important in terms of obtaining more accurate and rapid results clinically.
\end{abstract}

Keywords: artificial intelligence, machine learning, orthodontics 


\section{öz}

Amaç: Bilgi teknolojisinin ortodontide klinik kullanımı son yıllarda önemli ölçüde artmıştır. Bu sistematik derlemenin amacı, ortodonti alanındaki yapay zeka ve makine öğreniminin bilimsel bir analizini yapmaktır.

Gereç ve Yöntem: 25 Eylül 2018 tarihinde ortodonti yapay zeka ve makine öğrenimi hakkında elektronik arama ve el ile arama işlemleri gerçekleştirilmiştir.

Bulgular: Toplam 107 çalışma bulunmuştur. Dokuz çalışma, duplikasyon nedeniyle hariç tutulmuştur. Yazım dili İngilizce olmayan ve konuyla ilgisi olmayan makaleler hariç tutulduktan sonra, bu sistematik derleme için 23 tam metin makale incelenmiştir. Bu sistematik derlemeye 3 makale daha eklenmiştir. On iki otomatik sefalometrik işaret belirleme, 6 ortodontik tanı ve tedavi sonuçları, 2 ortodontik diş çekimi kararı, 3 yüz çekiciliği, 1 headgear seçimi, 1 dokunmatik sterilizasyon sistemi ve 1 otomatik iskelet yaşı tayini bu sistematik derlemede yer almıştır.

Sonuçlar: Yapay zeka ve makine öğrenimi, esas olarak otomatik sefalometrik nokta belirleme, yüz çekiciliği ve ortodontik amaç için diş çekimi kararlarının belirlenmesine odaklanmaktadır. Yapay zekanın ortodontide kullanılmasının klinik olarak daha doğru ve hızlı sonuçlar elde edilmesi açısından önem taşımaktadır.

Anahtar kelimeler: yapay zeka, makine öğrenmesi, ortodonti

\section{INTRODUCTION}

The clinical use of information technology in dentistry has increased significantly over the past 25 years. The use of technology, especially artificial intelligence (Al) and machine learning $(\mathrm{ML})$ technology, in medical and dental practices reduces cost, time, required human expertise and medical errors. Al is a concept that imitates human intelligence through computer technology. It allows examination, organization, representation and cataloguing of medical information. It also offers a rich discipline of content for future scientific medical expertise. Software that use Al techniques have some significant advantages over those that use more conventional methods. These programs have a greater capacity to quickly narrow down the number of diagnostics [1].

Orthodontic diagnoses generally require orthodontists to diagnose a patient from a comprehensive perspective, look at them from different points of view and evaluate various characteristics. This assessment process takes a lot of time, even for a single patient. In an orthodontic diagnosis, orthodontists are required to make a comprehensive diagnosis of the patient by evaluating multiple parts of the face from different perspectives rather than targeting the oral and maxillofacial region. Therefore, there is a need to automate diagnostic imaging to improve evaluation speed and accuracy $[2,3]$.

Cephalometry refers to the morphology of the craniofacial skeleton and skull measurements from lateral or anteroposterior cephalometric radiographs. Cephalometric radiographs are frequently used in conventional cephalometry, but unlike cone-beam computed tomography $(\mathrm{CBCT})$ which provides high-resolution images, they provide information in only one plane (coronal, sagittal or axial) from the $3 \mathrm{D}$ space. CBCT is widely used as a clinical and research instrument in assessment of complex malocclusions, oral and maxillofacial lesions and craniofacial deformities for orthodontic diagnosis and treatment planning. $C B C T$ naturally eliminates the limitations associated with conventional two-dimensional X-ray images and provides precise accuracy in bookmark planning with excellent reliability and repeatability. Manual cephalometric marking and monitoring are monotonous, difficult and time-consuming processes. Many orthodontists prefer not to follow cephalograms because of the time-consuming process of manual marking. Thus, an affordable, fast and automated 3-dimensional system of cephalometric marking for analysis may help diagnose the traditional disadvantages of cephalograms, such as overlapping bone structures and facial asymmetries, while increasing the effect on orthodontic practice and maintaining diagnostic protocols $[1,4-6]$.

The most important part of orthodontic treatment is to determine a treatment plan. A significant part of treatment planning is decision-making on tooth extraction before starting orthodontic treatment, as tooth extractions are irreversible. An incorrect decision may result in many problems during and after orthodontic treatment. Factors such as dental models, cephalometry and growth are considered primarily in deciding on tooth extraction by 


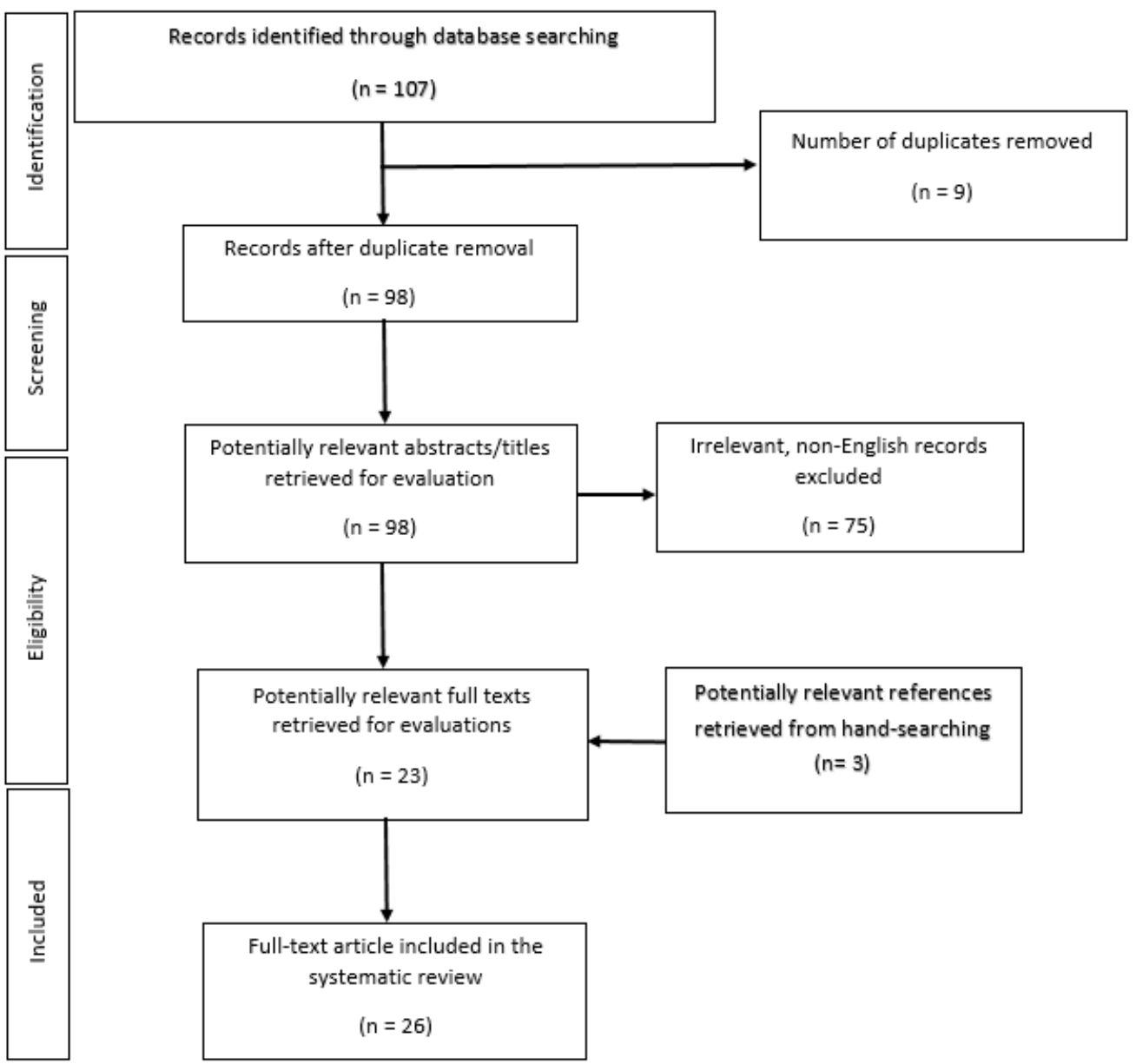

Figure 1. The flow diagram for the selection of studies

orthodontic treatment. Since such an assessment depends on a number of factors, it generally cannot provide general guidance for the practitioner; more precisely, the decision to extract teeth often requires a multifactorial analysis that includes the clinical experience of the orthodontist. Recent studies determined whether the patient needs to be imaged with high reliability on lateral cephalometric radiographs using neural network machine learning [7].

The aim of this systematic review was to perform a scientific analysis of artificial intelligence and machine learning in orthodontics.

\section{METHODS}

In this systematic review, articles were searched using PubMed on September 25, 2018 by Medline. PRISMA, which is used as a standard for systematic compilation and metaanalysis, was followed but not approved. Additionally, articles were manually scanned through Google Scholar and other databases. Manuscripts whose language was not English and those whose abstracts could not be reached were excluded. No restrictions were imposed on the publication year. In the last evaluation, articles in which orthodontics have reached the full text of $\mathrm{Al}$ and $\mathrm{ML}$ criteria were examined. The keywords 'machine learning AND orthodontics' and 'artificial intelligence AND orthodontics' were searched in PubMed. This study is a systematic review and the data were obtained on PubMed, so no ethics committee approval was required.

The literature search was conducted by one of the authors (S.K.B.), and the articles were selected independently by two authors (S.K.B. and S.H.) based on full texts, titles and abstracts. Publications that were not relevant or did not meet the specified search strategy were excluded. In the first round of the selection process, the titles and abstracts of the articles were evaluated, and the initially accepted studies were screened for eligibility.

\section{RESULTS}

A total of 107 studies were found in the initial searching step. Nine studies were excluded because of duplication. The remaining 98 studies were evaluated in terms of their relevance to the subject. After excluding 75 non-relevant and/or non-English studies, 23 full-text articles remained for this study. As a result of manual searching, 3 more articles were included in this systematic review. Consequently, 26 full-text articles were included in this study, and their results were shared (Figure 1) (Table 1). 
Table 1. Summary of the main characteristics of the studies for this systematic review

\begin{tabular}{|c|c|c|}
\hline \begin{tabular}{l|} 
Author, Year, Reference \\
Number
\end{tabular} & Title & Conclusion \\
\hline Patcas et al., (2018), (16) & $\begin{array}{l}\text { Applying artificial intelligence to assess the impact of } \\
\text { orthognathic treatment on facial attractiveness and } \\
\text { estimated age }\end{array}$ & $\begin{array}{l}\text { Artificial intelligence might be considered to score facial attractiveness and apparent } \\
\text { age in orthognathic patients. }\end{array}$ \\
\hline \begin{tabular}{|l|} 
Montufar et al., (2018), (5) \\
\end{tabular} & $\begin{array}{l}\text { Automatic 3-dimensional cephalometric landmarking } \\
\text { based on active shape models in related projections }\end{array}$ & $\begin{array}{l}\text { This study shows that a fast 2-dimensional landmark search can be useful for 3D } \\
\text { localization, which could save computational time compared with a full-volume } \\
\text { analysis. }\end{array}$ \\
\hline $\begin{array}{l}\text { Niño-Sandoval et al., } \\
(2017),(8)\end{array}$ & $\begin{array}{l}\text { Use of automated learning techniques for predicting } \\
\text { mandibular morphology in skeletal class I, II and III. }\end{array}$ & $\begin{array}{l}\text { This study may be the key to facial reconstruction from specific craniomaxillary } \\
\text { measures in the three skeletal classifications using artificial neural networks and } \\
\text { support vector regression. }\end{array}$ \\
\hline $\begin{array}{l}\text { Spampinato et al., (2017), } \\
(20)\end{array}$ & $\begin{array}{l}\text { Deep learning for automated skeletal bone age assessment } \\
\text { in X-ray images }\end{array}$ & $\begin{array}{l}\text { This study tests several deep learning approaches to assess skeletal bone age } \\
\text { automatically. }\end{array}$ \\
\hline Murata et. al., (2017), (2) & $\begin{array}{l}\text { Towards a fully automated diagnostic system for } \\
\text { orthodontic treatment in dentistry }\end{array}$ & $\begin{array}{l}\text { The authors proposed a deep convolutional neural network }(\mathrm{CNN}) \text { and the recurrent } \\
\text { neural network model with an attention mechanism to automate diagnostic imaging } \\
\text { for orthodontic treatment }\end{array}$ \\
\hline Wang et al., (2016), (18) & $\begin{array}{l}\text { Objective method for evaluating orthodontic treatment } \\
\text { from the lay perspective: An eye-tracking study }\end{array}$ & $\begin{array}{l}\text { The eye-tracking device was able to objectively quantify the effect of malocclusion on } \\
\text { facial perception and the impact of orthodontic treatment on malocclusion from the } \\
\text { lay perspective. }\end{array}$ \\
\hline \begin{tabular}{|l|} 
Jung and Kim, (2016), (7) \\
\end{tabular} & $\begin{array}{l}\text { New approach for the diagnosis of extractions with neural } \\
\text { network machine learning }\end{array}$ & $\begin{array}{l}\text { Artificial intelligence expert systems with neural network machine learning could be } \\
\text { useful in diagnosis of extractions orthodontics. }\end{array}$ \\
\hline $\begin{array}{l}\text { Wan Hassan et al., (2016), } \\
(12)\end{array}$ & $\begin{array}{l}\text { User acceptance of a touchless sterile system to control } \\
\text { virtual orthodontic study models }\end{array}$ & $\begin{array}{l}\text { The adoption of this promising development for a sterile touch-free patient record- } \\
\text { management system. }\end{array}$ \\
\hline $\begin{array}{l}\text { Nino-Sandoval et al., } \\
(2016),(9)\end{array}$ & $\begin{array}{l}\text { An automatic method for skeletal patterns classification } \\
\text { using craniomaxillary variables on a Colombian population. }\end{array}$ & $\begin{array}{l}\text { Support Vector Machines created an important model of classification of skeletal } \\
\text { patterns using craniomaxillary variables. }\end{array}$ \\
\hline Gupta et al., (2015), (4) & $\begin{array}{l}\text { A knowledge-based algorithm for automatic detection of } \\
\text { cephalometric landmarks on } \mathrm{CBCT} \text { images }\end{array}$ & $\begin{array}{l}\text { The proposed knowledge-based algorithm for automatic detection of landmarks on } \\
3 \mathrm{D} \text { images was able to achieve relatively accurate results than the currently available } \\
\text { algorithm. }\end{array}$ \\
\hline Auconi et. al., (2014), (21) & $\begin{array}{l}\text { Prediction of Class III treatment outcomes through } \\
\text { orthodontic data mining }\end{array}$ & $\begin{array}{l}\text { Fuzzy clustering repartition can be usefully used to estimate an individualized risk of } \\
\text { unsuccessful treatment outcome in Class III patients. }\end{array}$ \\
\hline Auconi et al., (2011), (22) & A network approach to orthodontic diagnosis & $\begin{array}{l}\text { Various types of malocclusion are characterized by different networks, suggesting the } \\
\text { possibility of novel orthodontic diagnostic and treatment approaches. }\end{array}$ \\
\hline Yagi et. al, (2010), (23) & $\begin{array}{l}\text { Decision-making system for orthodontic treatment } \\
\text { planning based on direct implementation of expertise } \\
\text { knowledge }\end{array}$ & $\begin{array}{l}\text { The decision-making system for orthodontic treatment planning was successfully } \\
\text { developed by implementing the expertise knowledge in the prediction algorithms for } \\
\text { the optimum decisions intuitively to demonstrate the prediction accuracy of } 90.5 \% \text {. }\end{array}$ \\
\hline $\begin{array}{l}\text { Tanikawa et.al., (2010), } \\
\text { (10) }\end{array}$ & $\begin{array}{l}\text { Automatic recognition of anatomic features on } \\
\text { cephalograms of preadolescent children }\end{array}$ & $\begin{array}{l}\text { The systems optimized in the present study for cephalograms of mixed dentition were } \\
\text { more accurate and reliable in recognizing the anatomic features on the cephalograms } \\
\text { of preadolescent children, compared with the previous system. }\end{array}$ \\
\hline Xie et al., (2010), (19) & $\begin{array}{l}\text { Artificial neural network modeling for deciding if } \\
\text { extractions are necessary prior to orthodontic treatment }\end{array}$ & $\begin{array}{l}\text { The constructed artificial neural network in this study was effective, with } 80 \% \\
\text { accuracy, in determining whether extraction or nonextraction treatment was best for } \\
\text { malocclusion patients between } 11 \text { and } 15 \text { years old. }\end{array}$ \\
\hline Mario et al., (2010), (24) & $\begin{array}{l}\text { Paraconsistent artificial neural network as auxiliary in } \\
\text { cephalometric diagnosis }\end{array}$ & $\begin{array}{l}\text { Paraconsistent artificial neural network is a promising theory in the cephalometric } \\
\text { analysis, opening a new promising tool of research in the health area. }\end{array}$ \\
\hline Kim et al., (2009), (25) & $\begin{array}{l}\text { Prognosis prediction for class III malocclusion treatment by } \\
\text { feature wrapping method }\end{array}$ & $\begin{array}{l}\text { The feature wrapping method, which uses a learning algorithm, might be an effective } \\
\text { alternative to discriminant analysis for prognosis prediction. }\end{array}$ \\
\hline $\begin{array}{l}\text { Banumathi et al., (2009), } \\
\text { (15) }\end{array}$ & $\begin{array}{l}\text { Diagnosis of Dental Deformities in Cephalometry Images } \\
\text { Using Support Vector Machine }\end{array}$ & $\begin{array}{l}\text { The accurate location estimation of the landmark is obtained using the recognizer, } \\
\text { which is as good as the performance of the expert dentists for a similar task. }\end{array}$ \\
\hline $\begin{array}{l}\text { Tanikawa et al., (2009), } \\
\text { (14) }\end{array}$ & $\begin{array}{l}\text { Automated cephalometry: system performance reliability } \\
\text { using landmark-dependent criteria }\end{array}$ & $\begin{array}{l}\text { The system successfully identified all specified anatomic structures in all the } \\
\text { cephalometric images and determined the positions of the landmarks with a mean } \\
\text { success rate of } 88 \% \text {. }\end{array}$ \\
\hline Noroozi, (2006), (26) & Orthodontic treatment planning software & $\begin{array}{l}\text { The computer program can propose treatment for some special cases, such as } \\
\text { incomplete dentition. }\end{array}$ \\
\hline $\begin{array}{l}\text { Rueda and Alcaniz, } \\
(2006),(13)\end{array}$ & $\begin{array}{l}\text { An approach for the automatic cephalometric landmark } \\
\text { detection using mathematical morphology and active } \\
\text { appearance models. }\end{array}$ & $\begin{array}{l}\text { Active appearance models combined with mathematical morphology is the suitable } \\
\text { method for clinical cephalometric applications. }\end{array}$ \\
\hline $\begin{array}{l}\text { Akçam and Takada, } \\
(2002),(27)\end{array}$ & Fuzzy modelling for selecting headgear types & $\begin{array}{l}\text { A fuzzy model that can infer precise choice of headgear types appropriate to the } \\
\text { treatment of an orthodontic case. }\end{array}$ \\
\hline Chen et al., (1999), (11) & $\begin{array}{l}\text { Improving cephalogram analysis through feature subimage } \\
\text { extraction }\end{array}$ & $\begin{array}{l}\text { The genetic algorithm is a good approach to speed up the process of feature } \\
\text { subimage extraction based on the fitness evaluated using the multilayer perceptron. }\end{array}$ \\
\hline
\end{tabular}


When the studies were examined, only 2 studies published before 2000 were included, and the interest in artificial intelligence increased after 2010.

12 of the studies included in the systematic review consist of those on machine learning and super vector analysis to automatically determine cephalometric points on threedimensional or two-dimensional radiography images [4-6,815]. Artificial intelligence and super vector machine were used in 3 studies that worked on facial attractiveness and perception [16-18]. Jung and Kim [7] and Xie et al. [19] evaluated the results of machine learning in deciding tooth extraction for orthodontic purposes. In the first and only study performed in 2017 [20], the authors evaluated handwrist radiographies automatically with the deep learning method in the evaluation of bone age. In three studies, deep convolutional neural network systems were used for orthodontic diagnosis. Six of these 26 articles described orthodontic diagnosis and treatment outcomes using $\mathrm{Al}$ and super vector regression [21-26]. Sterilization of the models was provided by a touchless sterile method in 1 study [27]. Headgear selection was performed by using the fuzzy method, which is one of the basic methods of artificial intelligence, in the study performed by Akçam and Takada [28].

\section{DISCUSSION}

In this systematic review, detailed information on 26 studies is presented. Twelve automatic cephalometric landmark determination, 6 orthodontic diagnosis and treatment outcomes, 2 orthodontic tooth extraction decision, 3 facial attractiveness, 1 headgear selection, 1 touchless sterilisation system and 1 automatic skeletal age determination studies were included in this study.

Recently, face assessment may be achieved by face analysis and interpretation through artificial intelligence by using facial identification with the expansion of application areas in the field of dentistry. Additionally, Al may be used in orthognathic surgery or to evaluate changes occurring in percentages using fixed or removable functional devices [16]. Al is also used to determine whether premolar teeth would be extracted using the artificial neural network model. Jung and Kim reported that Al and ML would be a new and reliable approach to detect tooth extraction in orthodontic treatment [7].
Montufar et al. [5]., in their study on CBCT images, performed automatic cephalometric point determination with artificial intelligence by using an active surface model, and they determined localisation with this method with a mean error value of $3.64 \mathrm{~mm}$ at 18 anatomical points. Most authors, such as Sella and Porion, reported more errors especially in areas such as irregular structures. Furthermore, Montufar et al. [6] performed 3-dimensional hybrid cystectomy on cone beam computed tomography images. Holistic threedimensional cephalometric point determination of 18 anatomical points was determined by a localisation error of $2.51 \mathrm{~mm}$.

Yu et al. [17] evaluated facial attractiveness by the ML method, and they reported that a combination of geometric morphometry and super vector regression methods could be used. Likewise, Patcas et al. [16] used artificial intelligence to evaluate the effects of changes that occur on the face with orthognathic surgery. Facial attractiveness and appearance were scored using algorithms on starting and ending photographs of 146 orthognathic surgery patients. The results of their study indicated that artificial intelligence may be used to evaluate facial attractiveness and apparent age in patients receiving orthognathic surgery.

A limitation of this systematic review was that we were not able to perform a meta-analysis due to the heterogeneity of the studies that were included.

\section{CONCLUSIONS}

This systematic review presents the areas of use of Al and ML in orthodontics. Nowadays, Al is mainly concentrated on orthodontics and determination of automatic cephalometric points, facial attractiveness and tooth extraction decisions for orthodontic purposes. Al and ML will be more dominant in the future in every field of dentistry especially in orthodontics. So, this issue on the topic of orthodontics is believed to need more studies to be carried out. The use of $\mathrm{Al}$ in orthodontics is thought to be clinically more accurate, and results may be achieved faster with this method.

\section{DECLARATION OF CONFLICT OF INTEREST}

The authors received no financial support for the research and/or authorship of this article. There is no conflict of interest. 


\section{REFERENCES}

1. Khanna S. Artificial intelligence: contemporary applications and future compass. Int Dent J 2010; 60: 269-72.

2. Murata S, Lee C, Tanikawa C, Date S. (2017, October). Towards a Fully Automated Diagnostic System for Orthodontic Treatment in Dentistry. In e-Science (eScience), 2017 IEEE 13th International Conference on (pp. 1-8). IEEE.

3. Leonardi R, Giordano D, Maiorana F, Spampinato C. Automatic cephalometric analysis. Angle Orthod 2008; 78: 145-51.

4. Gupta A, Kharbanda OP, Sardana V, Balachandran R, Sardana HK. A knowledge-based algorithm for automatic detection of cephalometric landmarks on CBCT images. Int J Comput Assist Radiol Surg 2015; 10: $1737-52$.

5. Montúfar J, Romero M, Scougall-Vilchis RJ. Automatic 3-dimensional cephalometric landmarking based on active shape models in related projections. Am J Orthod Dentofacial Orthop 2018; 153: 449-458.

6. Montúfar J, Romero M, Scougall-Vilchis RJ. Hybrid approach for automatic cephalometric landmark annotation on cone-beam computed tomography volumes. Am J Orthod Dentofacial Orthop 2018; 154: $140-150$.

7. Jung SK, Kim TW. New approach for the diagnosis of extractions with neural network machine learning. Am J Orthod Dentofacial Orthop 2016; 149: 127-33.

8. Niño-Sandoval TC, Guevara Pérez SV, González FA, Jaque RA, Infante-Contreras C. Use of automated learning techniques for predicting mandibular morphology in skeletal class I, II and III. Forensic Sci Int 2017; 281: 187.e1-187.e7.

9. Niño-Sandoval TC, Guevara Perez SV, González FA, Jaque RA, Infante-Contreras C. An automatic method for skeletal patterns classification using craniomaxillary variables on a Colombian population. Forensic Sci Int 2016; 261: 159.e1-6.

10. Tanikawa C, Yamamoto T, Yagi M, Takada K. Automatic recognition of anatomic features on cephalograms of preadolescent children. Angle Orthod 2010; 80: 81220.
11. Chen YT, Cheng KS, Liu JK. Improving cephalogram analysis through feature subimage extraction. IEEE Eng Med Biol Mag 1999; 18: 25-31.

12. Lévy-Mandel AD, Venetsanopoulos AN, Tsotsos JK. Knowledge-based landmarking of cephalograms. Comput Biomed Res 1986; 19: 282-309.

13. Rueda $S$, Alcañiz $M$. An approach for the automatic cephalometric landmark detection using mathematical morphology and active appearance models. Med Image Comput Comput Assist Interv 2006; 9: 159-66.

14. Tanikawa C, Yagi M, Takada K. Automated cephalometry: system performance reliability using landmark-dependent criteria. Angle Orthod 2009; 79: 1037-46.

15. Banumathi A, Raju S, Abhaikumar V. Diagnosis of dental deformities in cephalometry images using support vector machine. J Med Syst 2011; 35: 113-9.

16. Patcas R, Bernini DAJ, Volokitin A, Agustsson E, Rothe $R$, Timofte R. Applying artificial intelligence to assess the impact of orthognathic treatment on facial attractiveness and estimated age. Int J Oral Maxillofac Surg 2019; 48: 77-83.

17. $Y u$ X, Liu B, Pei $Y, X u$ T. Evaluation of facial attractiveness for patients with malocclusion: a machine-learning technique employing Procrustes. Angle Orthod 2014; 84: 410-6.

18. Wang X, Cai B, Cao Y, Zhou C, Yang L, Liu R, Long X, Wang W, Gao D, Bao B. Objective method for evaluating orthodontic treatment from the lay perspective: An eye-tracking study. Am J Orthod Dentofacial Orthop 2016; 150: 601-610.

19. Xie X, Wang L, Wang A. Artificial neural network modeling for deciding if extractions are necessary prior to orthodontic treatment. Angle Orthod 2010; 80: $262-6$

20. Spampinato $C$, Palazzo $S$, Giordano D, Aldinucci $M$, Leonardi R. Deep learning for automated skeletal bone age assessment in X-ray images. Med Image Anal 2017; 36: 41-51.

21. Auconi P, Scazzocchio M, Cozza P, McNamara JA Jr, Franchi L. Prediction of Class III treatment outcomes through orthodontic data mining. Eur J Orthod 2015; 37: 257-67. 
22. Auconi P, Caldarelli G, Scala A, lerardo G, Polimeni A. A network approach to orthodontic diagnosis. Orthod Craniofac Res 2011; 14: 189-97.

23. Yagi M, Ohno H, Takada K. Decision-making system for orthodontic treatment planning based on direct implementation of expertise knowledge. Conf Proc IEEE Eng Med Biol Soc 2010;2010:2894-7.

24. Mario MC, Abe JM, Ortega NR, Del Santo M Jr. Paraconsistent artificial neural network as auxiliary in cephalometric diagnosis. Artif Organs 2010; 34: E21521.
25. Kim BM, Kang BY, Kim HG, Baek SH. Prognosis prediction for Class III malocclusion treatment by feature wrapping method. Angle Orthod 2009; 79: 683-91.

26. Noroozi H. Orthodontic treatment planning software. Am J Orthod Dentofacial Orthop 2006; 129: 834-7.

27. Wan Hassan WN, Abu Kassim NL, Jhawar A, Shurkri NM, Kamarul Baharin NA, Chan CS. User acceptance of a touchless sterile system to control virtual orthodontic study models. Am J Orthod Dentofacial Orthop 2016; 149: 567-78.

28. Akçam MO, Takada K. Fuzzy modelling for selecting headgear types. Eur J Orthod 2002; 24: 99-106. 